Received $\quad 13.01 .2018$

Reviewed 19.07 .2018

Accepted 20.08.2018

A - study design

B - data collection

C - statistical analysis

D - data interpretation

$\mathbf{E}$ - manuscript preparation

F - literature search

\title{
Evaluation of heavy metal contamination in sediments of the Seybouse River, Guelma - Annaba, Algeria
}

\author{
Hanane TALBI $^{\text {BCDEF }}$, Slimane KACHI ${ }^{\mathrm{AE} \otimes}$
}

University 8 may 1945, Faculty of Nature and Life Sciences and Earth and Universe Sciences, Department of Biology, P.O Box 401, 24000 Guelma, Algeria; e-mail: t_hanane@yahoo.com; skachidz@yahoo.fr

For citation: Talbi H., Kachi S. 2019. Evaluation of heavy metal contamination in sediments of the Seybouse River, Guelma - Annaba, Algeria. Journal of Water and Land Development. No. 40 (I-III) p. 81-86. DOI: 10.2478/jwld-2019-0008.

\begin{abstract}
The surface sediments of Seybouse River and its affluents have been studied and assessed to determine their degree of heavy metal contamination $(\mathrm{Cd}, \mathrm{Pb}, \mathrm{Cu}, \mathrm{Ni}, \mathrm{Zn}$ and $\mathrm{Fe})$. The contamination factor $(C F)$, the contamination degree $(C D)$ and statistical tools (correlation and APC) has been used in assessing: metal contamination, sediment toxicity and to identify the origin of metals which have enriched the sediments. Heavy metals concentrations of sediments are generally heterogeneous and vary according to the metal and the sampling site. The results have been compared to the reference values of the unpolluted sediments and have shown that Seybouse River sediments are more contaminated by $\mathrm{Pb}, \mathrm{Cd}$ and $\mathrm{Zn}$ respectively. $\mathrm{CF}$ values indicate moderate to considerable contamination for most stations. $C D$ values show that the most toxic sediments are located mainly at the estuary and downstream of large agglomerations. The matrix correlation between the metallic elements shows a very strong correlation between $\mathrm{Pb}, \mathrm{Cd}, \mathrm{Cu}$ and $\mathrm{Zn}$ indicating that they have a similar source. These different metallic elements appear as traces of anthropogenic pollution. Despite using wastewater treatment plants as protective measures, Seybouse River pollution is remaining a big issue and more efforts has to be done by local authorities.
\end{abstract}

Key words: contamination, Guelma - Annaba basin, heavy metals, sediments, Seybouse River

\section{INTRODUCTION}

Metallic contamination of aquatic environments has become a global concern over the world due to uncontrolled industrial and urban discharges, the intensive use of chemical fertilizers and pesticides in agriculture as well as the non-rational use of water resources.

The contaminants that reach these environments constitute always a major environmental problem. The concentration of most of contaminants rises sometimes up to levels which are very toxic.

Among these pollutants, metal residues which are considered as serious pollutants that could affect the aquatic life as well as human health through the use of water (food, agriculture) [COOK et al. 1990; DENISEGER et al. 1990].

Heavy metals from natural or anthropogenic sources released into an aquatic environment are largely trapped in sediments [SIN et al. 2001]. As a result, sediments are often used to assess the degree of pollution of aquatic environments [BUGGY, TOBIN 2008].
In the catchment area of Guelma-Annaba, Seybouse River represents a fundamental source of life for these regions and the water is used for domestic, industrial and agricultural purposes. These activities associated with urbanization and wastewater discharges without prior treatment are the potential sources of heavy metals that threaten water quality of the Seybouse River.

Many studies have already been carried out on the study area [ATTOUI et al. 2016; BOURHANE-EDDINE 2010; DEBIECHE 2002; KHALED-KHODJA et al. 2016; LARABA, HADJ ZOBIR 2009], indicating the main role of the industry, agriculture and wastewater in the deterioration of water quality. The World Bank (1996) intervened to finance a study in the region, in order to control pollution at ElHadjar steel complex. According to the Ministry of Spatial Planning, Environment and City [Ministère de l'Aménagement du Territoire et de l'Environnement 2007], the pollution reaches a high degree.

With all these changes and important anthropogenic activities, these regions are aroused a strong concern and 
growing interest to study its consequences on the water quality and the environment.

It is in this context, this study has been conducted to assess the level of heavy metals pollution of Seybouse River through the analysis of sediments.

\section{MATERIALS AND METHODS}

\section{STUDY AREA}

The Seybouse basin is located in the northeastern region of Algeria and covers an area of $6471 \mathrm{~km}^{2}$ and its lands are more fertile. Annual rainfall varies on average from $450 \mathrm{~mm}$ in the south to $735 \mathrm{~mm}$ in the North. The Seybouse River is formed near Guelma by the confluence of the Cherf River and the Bouhamdane River, it joins the Mediterranean Sea near Annaba (Fig. 1).

\section{SAMPLING}

The sampling area is spread out over the entire length of Seybouse, from the confluence (near Guelma) to the estuary (Annaba).
The sampling points have been divided according to the strategic locations of the Seybouse River, downstream of the affluents, agglomerations and industrial zones likely to be the source of the pollution. The sampling campaign has been conducted in July 2015.

A set of thirty-one stations has been considered in this study where eighteen among the Seybouse River and thirteen from its affluents (Fig. 1). In a plastic hand shovel, approximately, a quantity of $500 \mathrm{~g}$ of wet sediment is collected in vacuum-sealed polyethylene bags and carried-out to the laboratory at $4^{\circ} \mathrm{C}$. Then, the sediments are dried at $105^{\circ} \mathrm{C}$ for 48 hours to eliminate moisture. After drying process, the sediments are ventilated, milled and sieved through the $63 \mu \mathrm{m}$ sieve. Five grams of sediment are weighed and put in a $100 \mathrm{ml}$ beaker with $70 \mathrm{~cm}^{3}$ of bidistilled water, $25 \mathrm{~cm}^{3}$ of nitric acid $\left(\mathrm{HNO}_{3}\right)$ and $5 \mathrm{~cm}^{3}$ of hydrochloric acid $(\mathrm{HCl})$, brought to a gentle boiling on a sand bath for 24 hours, allowed to cool and resumed by adding a few drops of $1 \mathrm{~mol}$ per $1 \mathrm{HCl}$. Next, samples are filtered using a cellulose membrane without ash, and then adjusted to $100 \mathrm{~cm}^{3}$ with $\mathrm{HCl}(37 \%)$ solution [AMINOT, CHAUSSEPIED 1983].

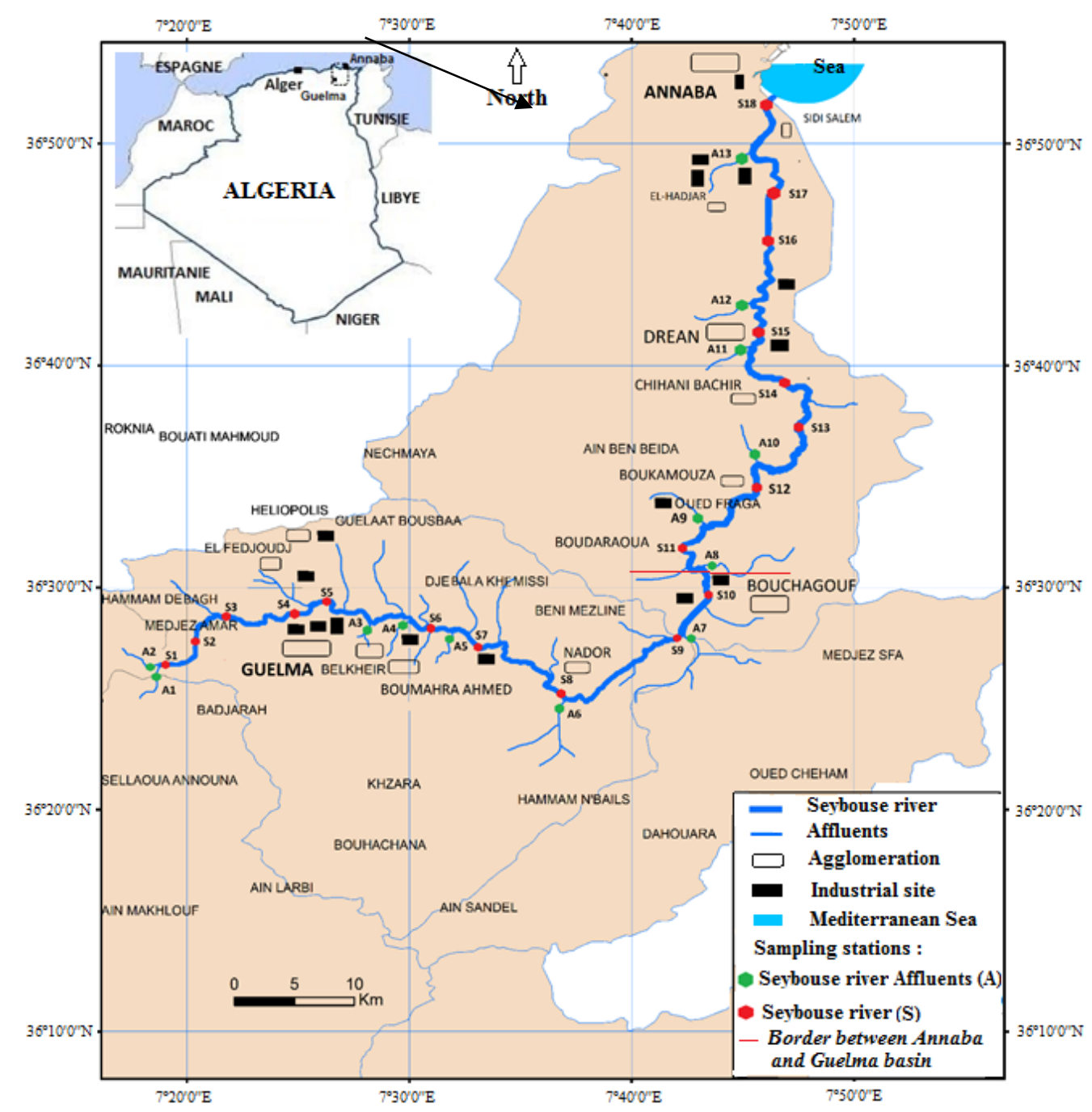

Fig. 1. Location of the study area and sampling stations on the Seybouse River and its affluents (Guelma - Annaba Basin); source: own elaboration 
The trace elements $(\mathrm{Fe}, \mathrm{Cu}, \mathrm{Zn}, \mathrm{Ni}, \mathrm{Cd}, \mathrm{Pb})$ are analysed by flame atomic absorption spectrophotometer Thermo Electron Corporation MGF95Z series, with the hollow cathode lamp which emits the wavelength corresponding to the analysed element (toxicology laboratory, National Institute of Forensic Sciences and Criminology (Fr. Institut National de Criminalistique et de Criminologie) in Algiers.
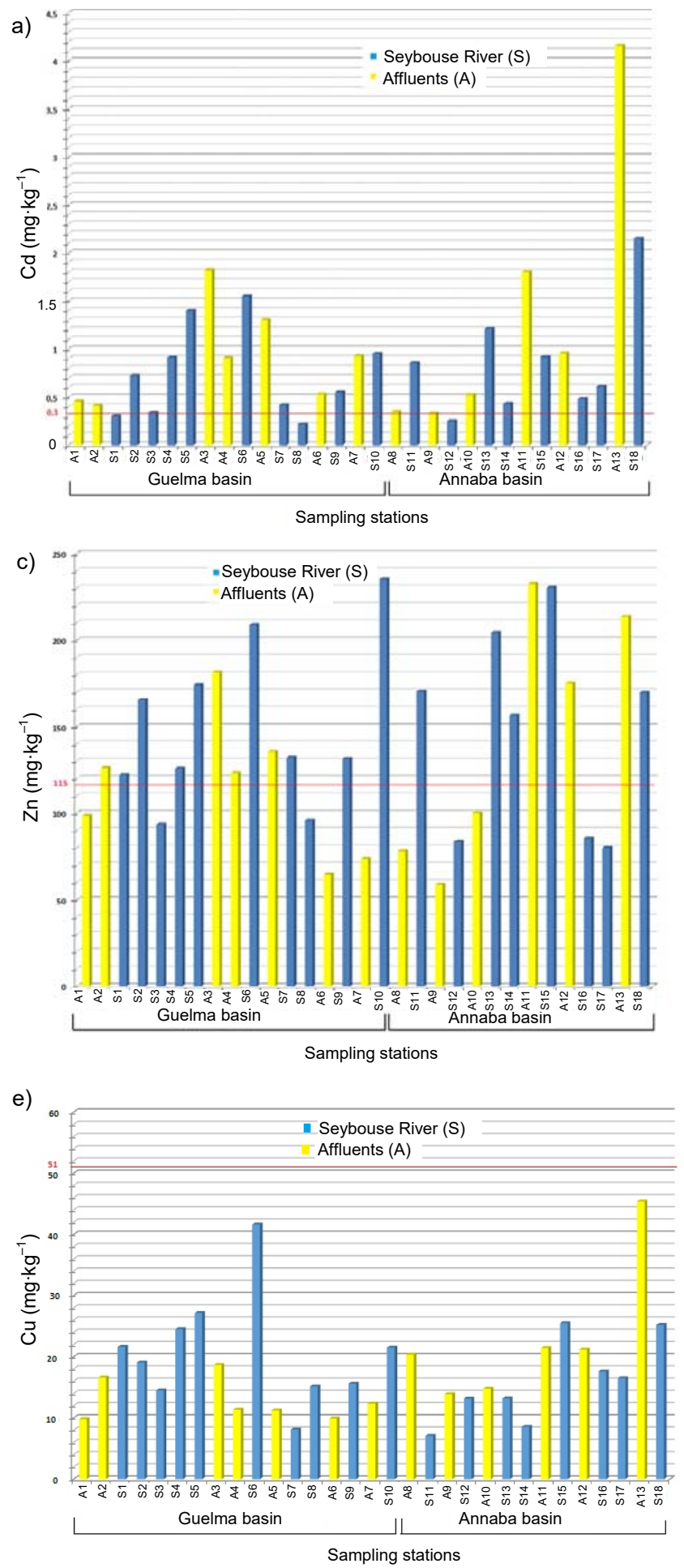

\section{RESULTS AND DISCUSSION}

The results reveal the presence of $\mathrm{Cd}, \mathrm{Cu}, \mathrm{Ni}, \mathrm{Fe}, \mathrm{Pb}$ and $\mathrm{Zn}$ in all sampling stations as shown in Figure 2. It can clearly be seen that the order of abundance is: $\mathrm{Fe}>\mathrm{Zn}>$ $\mathrm{Pb}>\mathrm{Cu}>\mathrm{Ni}>\mathrm{Cd}$. The heavy metal concentrations have been compared to average reference concentrations in unpolluted sediments [FÖRSTNER, SALOMONS 1980].
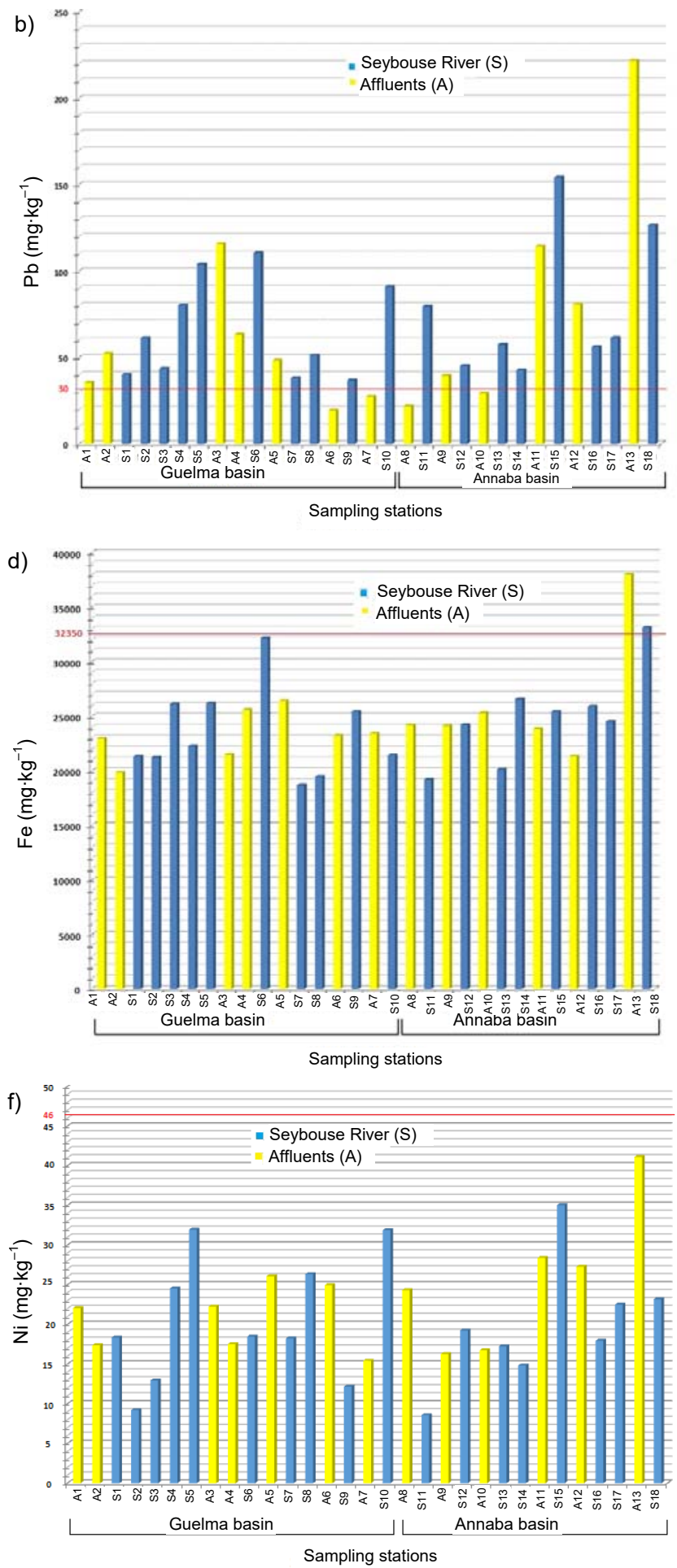

Fig. 2. Metal contents in the sediments of the Seybouse River and its affluents; a) Cd, b) Pb, c) $\mathrm{Zn}, \mathrm{d}$ ) $\mathrm{Fe}$, e) $\mathrm{Cu}, \mathrm{f}) \mathrm{Ni}$; sampling stations as in Fig. 1; source: own study 
The concentration of $\mathrm{Cd}$ and $\mathrm{Pb}$ exceeds the average standard of reference of unpolluted sediments in the majority of sampling stations (Fig. 2a, b). The values of $\mathrm{Cd}$ from 0.219 to $4.158 \mathrm{mg} \cdot \mathrm{kg}^{-1}$ exceed the unpolluted sediment limit $\left(0.3 \mathrm{mg} \cdot \mathrm{kg}^{-1}\right)$, the maximum value is found on the affluent of the Meboudja River which drains wastewater from El-Hadjar steel complex and the industrial zone of Pont-Boucher. Similarly, for $\mathrm{Pb}$, it varies from 21.82 to $221.8 \mathrm{mg} \cdot \mathrm{kg}^{-1}$ whereas the value of the unpolluted sediment is $30 \mathrm{mg} \cdot \mathrm{kg}^{-1}$. Thus, only three values are below this limit while the maximum value is observed at the affluent of the Meboudja River. The significant concentrations of $\mathrm{Cd}$ and $\mathrm{Pb}$ are related to anthropogenic carried by the Seybouse River and its affluents resulting in a general contamination.

The contents of $\mathrm{Zn}$ recorded in the sediments of Seybouse River and its affluents show values ranging from 58.8 to $235.2 \mathrm{mg} \cdot \mathrm{kg}^{-1}$ (Fig. 2c). The maximum values are observed in station S10 $\left(235.2 \mathrm{mg} \cdot \mathrm{kg}^{-1}\right)$ of Bouchegouf followed by station A11 $\left(230.4 \mathrm{mg} \cdot \mathrm{kg}^{-1}\right)$ on the affluent of the Djefli River and station S15 $\left(213.6 \mathrm{mg} \cdot \mathrm{kg}^{-1}\right)$ at Drean entrance. These values are significantly higher than the value of unpolluted sediments $\left(115 \mathrm{mg} \cdot \mathrm{kg}^{-1}\right)$.

Iron concentrations vary from 18685 to 37990 $\mathrm{mg} \cdot \mathrm{kg}^{-1}$ where only in two stations have recorded values above the standard limit $\left(32350 \mathrm{mg} \cdot \mathrm{kg}^{-1}\right.$ ). The two stations are: A13 $\left(37990 \mathrm{mg} \cdot \mathrm{kg}^{-1}\right)$ located at the affluent of the Meboudja River, and S18 (33 $120 \mathrm{mg} \cdot \mathrm{kg}^{-1}$ ) at the Seybouse River last station before the estuary (Fig. 2d). Both stations are located in the downstream of El-Hadjar steel complex reflecting its influence on river sediments contamination.

In contrast to these elements, the $\mathrm{Cu}$ and $\mathrm{Ni}$ contents do not exceed the limit for unpolluted sediment at all stations, ranging respectively from 7.09 to $45.41 \mathrm{mg} \cdot \mathrm{kg}^{-1}$ and from 8.58 to $41.13 \mathrm{mg} \cdot \mathrm{kg}^{-1}$, thus reflecting the geochemical background at all stations of the study area (Fig. 2e, f).

The spatial distribution of trace metals shows relatively high concentrations in both middle and lower basin and it is mainly located in the downstream of agglomerations and industrial sites.

The most polluted areas in the Guelma basin are located in: A3 (affluent of the El-maiz River), S6 (the Seybouse River) where the wastewater is coming from the residential city of Guelma and industry plants, S6 (the Seybouse River) which wastewater is coming from Bouchegouf city.

The most polluted areas in Annaba basin are: A11 and A13 where the wastewater is coming from Drean city and affluent of the Meboudja River, respectively. They are considered as the most polluted areas based on our analysis. It's main wastewater coming from the El-Hadjar steel plant and Pont-Boucher industrial plant. Finally, S18 represents the last sampling station of the river with the sea

The analysis of the results points out the impact of anthropogenic carried by the Seybouse River and its affluents on the pollution within many areas.

The contamination factor $(C F)$ has been used to express the level of contamination for each metal in the sediments where: $C F=$ (metal content in the sediment $) /($ metal background).
The background of the metal indicates the concentration of the metal (of interest) in the sediments where there was no anthropogenic input. Due to the lack of availability of the geochemical background in the Seybouse River system and its affluents, specific concentrations are used as background to shale substrates defined by FÖRSTNER and SALOMONS [1980].

$C F$ values are interpreted by HAKANSON [1980], where:

$C F<1$ indicates low contamination;

$1<C F<3$ is moderate contamination;

$3<C F<6$ is significant contamination;

$C F>6$ is very high contamination.

The sediments of the thirty-one sampling stations in the Seybouse River and its affluents have $C F$ in $\mathrm{Cd}$ and $\mathrm{Pb}$ almost all greater than 1 . Therefore, enrichment or a contamination by these elements exists and is considered extremely toxic for the fauna.

Contamination is moderate to very high for $\mathrm{Cd}$ and moderate to significant for $\mathrm{Pb}$. In contrast, $\mathrm{Cu}$ and $\mathrm{Ni}$ enrichments are low.

$C F-\mathrm{Cu}$ and $C F-\mathrm{Ni}$ never exceed the first class threshold $(C F<1)$ resulting in low or insignificant contamination regardless of the sampling point.

$C F$ values for $\mathrm{Zn}$ and $\mathrm{Fe}$ are at least 1 in all the river measured stations and its affluents resulting in a low to moderate pollution for these two elements.

The degree of contamination $(C D i)$ is the sum of the $C F$. It allows the estimation of the a priori polymetallic contamination for each sampling point. It is calculated according to the following formula:

$$
C D i=\sum C F i
$$

This index is associated with four quality classes [HAKANSON 1980]:

$C D<6$ indicates low contamination,

$6 \leq C D<12$ is moderate contamination,

$12 \leq C D<24$ is considerable contamination,

$24 \leq C D$ is very high contamination.

The results in Table 1 show that polymetallic contamination mainly of two or more elements. The $C D$ results are under the threshold defined by HAKANSON [1980] leading to a very small contamination. It can be noticed that A13 station (Meboudja) has a high contamination degree of 26.688 related mainly to $\mathrm{Cd}$ and $\mathrm{Pb}$. This situation can be explained by the wastewater coming from El-Hadjar steel plant, the industrial area of Pont Boucher and the surrounding residential areas.

Two statistical methods have been used to complement the interpretation tools of the sediments obtained data. Pearson correlation matrix has been used to find out the relation between the metals on one hand. On the other hand, it has been used to verify the similarity of the origin of those metals in the sediments of the Seybouse River and its affluents (Tab. 2). A significant correlation exists between the metallic elements of $\mathrm{Pb}, \mathrm{cd}, \mathrm{Cu}, \mathrm{Zn}$ and the $\mathrm{Ni}$ leading to the conclusion that they are from similar anthropic activity sources such urban and industrial wastes or the runoff of acidic agricultural soils with strong content of pesticides and mineral fertilizers [N'GUESSAN 2008]. Iron 
Table 1. The contamination factor $(C F)$ and the degree of contamination $(C D)$ of sediments of the different studied stations

\begin{tabular}{|c|c|c|c|c|c|c|c|c|}
\hline \multirow{2}{*}{ Area } & \multirow{2}{*}{$\begin{array}{l}\text { Station } \\
\text { code }^{1)}\end{array}$} & \multicolumn{6}{|c|}{$C F$} & \multirow{2}{*}{$C D$} \\
\hline & & $\mathrm{Fe}$ & $\mathrm{Ni}$ & $\mathrm{Cu}$ & $\mathrm{Zn}$ & $\mathrm{Cd}$ & $\mathrm{Pb}$ & \\
\hline \multirow{17}{*}{ 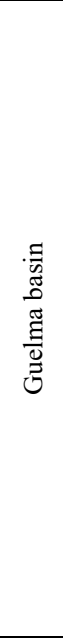 } & $\mathrm{A} 1$ & 1.077 & 0.480 & 0.193 & 0.857 & 1.520 & 1.188 & 5.315 \\
\hline & A2 & 0.931 & 0.378 & 0.326 & 1.098 & 1.377 & 1.737 & 5.847 \\
\hline & S1 & 1.000 & 0.399 & 0.424 & 1.063 & \begin{tabular}{|l|}
1.007 \\
\end{tabular} & 1.340 & 5.233 \\
\hline & S2 & 0.996 & 0.200 & 0.374 & 1.439 & 2.410 & 2.049 & 7.468 \\
\hline & S3 & 1.225 & 0.282 & 0.285 & 0.814 & 1.140 & 1.488 & 5.234 \\
\hline & S4 & 1.044 & 0.534 & 0.481 & 1.094 & 3.040 & 2.674 & 8.867 \\
\hline & S5 & 1.228 & 0.695 & 0.533 & 1.514 & 4.670 & 3.464 & 12.104 \\
\hline & A3 & 1.008 & 0.484 & 0.367 & 1.577 & 6.070 & 3.858 & 13.446 \\
\hline & A4 & 1.201 & 0.381 & 0.223 & 1.072 & \begin{tabular}{|l|}
3.023 \\
\end{tabular} & 2.110 & 8.010 \\
\hline & S6 & 1.509 & 0.402 & 0.817 & 1.816 & \begin{tabular}{|l|}
5.170 \\
\end{tabular} & 3.684 & 13.398 \\
\hline & A5 & 1.239 & 0.567 & 0.221 & 1.178 & 4.347 & 1.612 & 9.164 \\
\hline & S7 & 0.877 & 0.397 & 0.159 & 1.149 & 1.393 & 1.274 & 5.249 \\
\hline & S8 & 0.912 & 0.573 & 0.298 & 0.834 & 0.730 & 1.710 & 5.057 \\
\hline & A6 & 1.090 & 0.543 & 0.195 & 0.563 & 1.770 & 0.647 & 4.808 \\
\hline & S9 & 1.192 & 0.265 & 0.306 & 1.143 & 1.840 & 1.228 & 5.974 \\
\hline & A7 & 1.099 & 0.336 & 0.243 & 0.641 & 3.090 & 0.917 & 6.326 \\
\hline & S10 & 1.006 & 0.694 & 0.422 & 2.045 & 3.170 & 3.031 & 10.368 \\
\hline \multirow{14}{*}{ 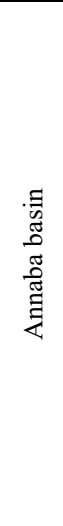 } & A8 & 1.134 & 0.529 & 0.400 & 0.679 & 1.163 & 0.727 & 4.632 \\
\hline & S11 & 0.900 & 0.187 & 0.139 & 1.482 & 2.853 & 2.654 & 8.215 \\
\hline & A9 & 1.131 & 0.354 & 0.273 & 0.511 & 1.113 & 1.316 & 4.698 \\
\hline & S12 & 1.136 & 0.419 & 0.259 & 0.727 & 0.840 & 1.512 & 4.893 \\
\hline & A10 & 1.187 & 0.364 & 0.290 & 0.870 & 1.750 & 0.976 & 5.437 \\
\hline & S13 & 0.944 & 0.375 & 0.259 & 1.776 & 4.043 & 1.918 & 9.315 \\
\hline & S14 & 1.247 & 0.323 & 0.168 & 1.362 & \begin{tabular}{|l|}
1.437 \\
\end{tabular} & 1.424 & 5.961 \\
\hline & A11 & 1.118 & 0.618 & 0.420 & 2.022 & 6.023 & 3.809 & 14.010 \\
\hline & S15 & 1.192 & 0.762 & 0.500 & 2.003 & 3.063 & 5.145 & 12.665 \\
\hline & A12 & 1.000 & 0.593 & 0.416 & 1.523 & 3.187 & 2.694 & 9.413 \\
\hline & S16 & 1.215 & 0.391 & 0.345 & 0.743 & 1.603 & 1.875 & 6.172 \\
\hline & S17 & 1.149 & 0.490 & 0.324 & 0.697 & 2.037 & 2.052 & 6.749 \\
\hline & A13 & 1.792 & 0.894 & 0.891 & 1.857 & 13.860 & 7.394 & 26.688 \\
\hline & S18 & 1.554 & 0.504 & 0.495 & 1.476 & 7.173 & 4.219 & 15.421 \\
\hline
\end{tabular}

1) Stations as in Fig. 1.

Source: own study.

Table 2. Pearson correlation matrix of metallic elements in sediments of the Seybouse River and its affluents.

\begin{tabular}{|c|c|c|c|c|c|c|}
\hline Element & $\mathrm{Pb}$ & $\mathrm{Cd}$ & $\mathrm{Cu}$ & $\mathrm{Zn}$ & $\mathrm{Ni}$ & $\mathrm{Fe}$ \\
\hline $\mathrm{Pb}$ & 1 & & & & & \\
\hline $\mathrm{Cd}$ & $0.861^{* *}$ & 1 & & & & \\
\hline $\mathrm{Cu}$ & $0.775^{*}$ & 0.670 & 1 & & & \\
\hline $\mathrm{Zn}$ & $0.748^{*}$ & 0.611 & 0.523 & 1 & & \\
\hline $\mathrm{Ni}$ & 0.646 & 0.561 & 0.570 & 0.408 & 1 & \\
\hline $\mathrm{Fe}$ & 0.571 & 0.675 & 0.662 & 0.200 & 0.361 & 1 \\
\hline
\end{tabular}

Explanations: * the correlation is significant at the 0.05 level (bilateral); ** the correlation is significant at the 0.01 level (bilateral).

Source: own study.

does not have significant correlation compared to other elements within the analysed area. Therefore, it has a lithological source.

Principal Component Analysis (PCA) identifies factors (measured parameters or sampling stations) that have contributed most to the construction of the main components [MASSON et al. 2006]. This type of analysis often makes it possible to discover particular associations between pa- rameters or between sampling stations, thus giving clues to the processes of contamination of the sediments of the river or the origin of certain heavy metals. Both methods are employed using the XLSTAT 2017 software.

The analysis of Figure 3, based on the representation of two factors (F1-F2), expressing $81.04 \%$ of the total variability of the point cloud, corroborates the existence of an association between $\mathrm{Pb}, \mathrm{Cd}, \mathrm{Cu}$ and $\mathrm{Ni}$. Moreover, the projection of the sampling stations (Fig. 3) made it possible to distinguish two groups:

- group I represented by the stations A3, A11, A12, A13, S6, S10 and S18; all these stations are characterized by a considerable degree of contamination;

- group II includes the rest of the stations with low levels of heavy metals.

Despite using wastewater treatment plants as protective measures, the Seybouse River pollution is remaining a big issue and more efforts has to be done by local authorities.

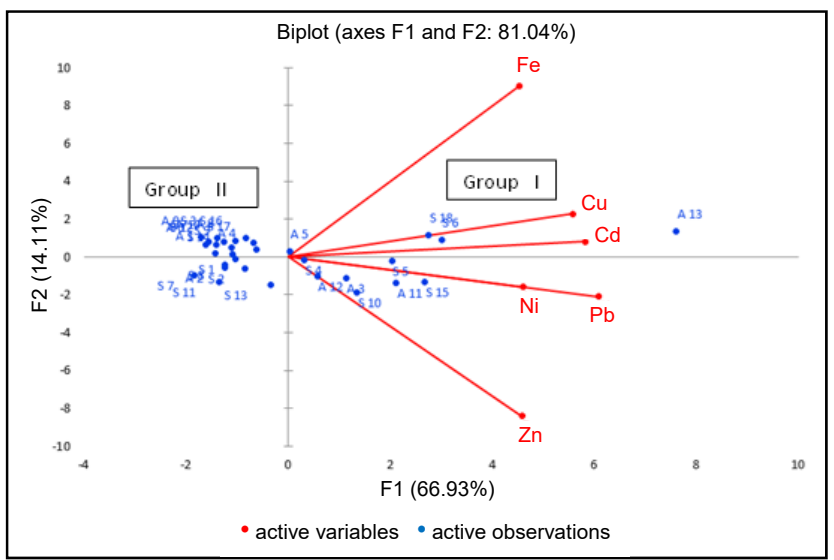

Fig. 3. Results of the principal component analysis for heavy metal values analysed in the Seybouse River sediments and its affluents; sampling stations as in Fig. 1; source: own study

\section{CONCLUSIONS}

The obtained results in this work allowed us to evaluate and assess the Seybouse River heavy metal contamination in surface sediments. The heavy metal contents show enrichment by $\mathrm{Cd}, \mathrm{Pb}$ and $\mathrm{Zn}$. This inventory reflects the direct influences of the anthropogenic contributions conveyed by the Seybouse River and its affluents in its basins Guelma and Annaba. Cadmium and lead contamination is generalized and has affected all stations.

Metallic contamination assessment indices $(C F$ and $C D$ ) conclude that these high levels of heavy metals are predominantly anthropogenic. The significant positive correlation observed between $\mathrm{Pb}, \mathrm{Cd}$ and $\mathrm{Zn}$ metallic elements confirms that these metals have similar sources. These sources of metal pollution are related to the potential causes and threats of pollution in the Seybouse River and its affluents and are closely related to the intense human activity. 


\section{REFERENCES}

Aminot A., Chaussepied M. 1983. Manuel des analyses chimiques en milieu marin [Manual of chemical analyzes in marine environment]. Brest. CNEXO. ISBN 2902721102 pp. 396.

Attoui B., Toumi N., Messaoudi S., Benrabah S. 2016. Degradation of water quality: The case of plain west of Annaba (northeast of Algeria). Journal of Water and Land Development. No. 31 p. 3-10. DOI 10.1515/jwld2016-0031.

BOURHANE-EDDINE B. 2010. La pollution par les métaux lourds dans la région d'Annaba "Sources de contamination des écosystèmes aquatiques» [Heavy metals pollution in the Annaba region "Contamination sources of aquatic ecosystems"]. PhD Thesis. Annaba. Université Badji Mokhtar pp. 176.

BugGy C.J., ToBin J.M. 2008. Seasonal and spatial distribution of metals in surface sediment of an urban estuary. Environmental Pollution. Vol. 155. Iss. 2 p. 308-319.

COOK J.A., ANDREW S.M., JOHNSON M.S. 1990. Lead, zinc, cadmium and fluoride in small mammals from contaminated grass-land established on fluorspar tailings. Water, Air and Soil Pollution. Vol. 51. Iss. 1-2 p. 43-54.

DeBIECHE T.H. 2002. Évolution de la qualité des eaux (salinité, azote et métaux lourds) sous l'effet de la pollution saline, agricole et industrielle. Application à la basse plaine de la Seybouse, Nord-Est Algérie [Evolution of water quality (salinity, nitrogen and heavy metals) as a result of salt, agricultural and industrial pollution. Application to the low plain of Seybouse, North-East Algeria]. PhD Thesis. Besançon. Université de Franche-Comté pp. 199.

Deniseger J., ERickson L.J., Austin A., Roch M., Clark M.J.R. 1990. The effects of decreasing heavy metal concentrations on the biota of Buttle Lake, Vancouver Island, British Columbia. Water Resources. Vol. 24. Iss. 4 p. 403416.
FÖRSTNER U., SALOMONS W. 1980. Trace metal analysis on polluted sediments. P. 1: Assessment of sources and intensities. Environmental Technology Letters. Vol. 1 p. 494-505.

HAKANSON L. 1980. Ecological risk index for aquatic pollution control. A sedimentological approach. Water Research. Vol. 14. Iss. 5 p. 975-1001. DOI 10.1016/0043-1354(80)90143-8.

Khaled-Khodja S., Samar M.H., Durand G. 2016. Contamination métallique de l'eau et du sédiment d'Oued Bouhamra [Metal contamination of water and sediment from Wadi Bouhamra]. Synthèse: Revue des Sciences et de la Téchnologie. No. 32 p. 135-146.

Laraba A., Hadj Zobir S. 2009. Pollution organique des eaux d'oued Seybouse (Plaine alluviale de Guelma, Nord-Est Algérien) [Organic pollution of Seybouse River (Alluvial Plain of Guelma, North-East Algeria]. Bulletin des sciences géographiques. No. 23 ( $1^{\text {er }}$ semestre 2009) p. 2-6.

Masson M., Blanc G., Schafer J. 2006. Geochemical signals and source contributions to heavy metal $(\mathrm{Cd}, \mathrm{Zn}, \mathrm{Pb}, \mathrm{Cu})$ fluxes into the Gironde Estuary via its major tributaries. Science of the Total Environment. Vol. 370 p. 133-146.

Ministère de l'Aménagement du Territoire et de l'Environnement 2007. Rapport National sur l'état et l'avenir de l'environnement (RNEAE) [National Report on the state and future of the environment ]. Algeria pp. 482.

N'GUESSAN Y.M. 2008. Dynamique des éléments traces dans les eaux de surface des bassins versants agricoles de Gascogne [Dynamics of trace elements in surface waters of agricultural catchment areas of Gascony]. PhD Thesis. Toulouse. INPTENSAT-Ecolab pp. 253.

Sin S.N., ChUA H., Lo W., NG L.M. 2001. Assessment of of heavy metal cations in sediments of Shing Mun River, Hong Kong. Environmental International. Vol. 26. Iss. 5-6 p. 297301.

\section{Hanane TALBI, Slimane KACHI}

\section{Ocena zanieczyszczenia metalami ciężkimi osadów w rzece Seybouse, Guelma - Annaba, Algieria}

\section{STRESZCZENIE}

Analizowano powierzchniowe osady rzeki Seybouse i jej dopływów, aby określić stopień ich zanieczyszczenia metalami ciężkimi ( $\mathrm{Cd}, \mathrm{Pb}, \mathrm{Cu}, \mathrm{Ni}, \mathrm{Zn}$ i Fe). Do oceny zanieczyszczenia metalami osadów i ich toksyczności oraz do identyfikacji pochodzenia metali, które wzbogaciły osady, wykorzystano współczynnik zanieczyszczenia $(C F)$, stopień zanieczyszczenia $(C D)$ oraz narzędzia statystyczne (korelacja i analiza głównych składowych). Zawartość metali ciężkich była zróżnicowana zarówno między metalami, jak i między stanowiskami badawczymi. Wyniki porównane z wartościami referencyjnymi z niezanieczyszczonych osadów wykazały, że osady rzeki Seybouse są zanieczyszczone ołowiem, kadmem i cynkiem. Wartości $C F$ wskazują umiarkowane do znaczącego zanieczyszczenia większości stanowisk. Wartości $C D$ świadczą, że najbardziej toksyczne osady zlokalizowane są głównie w estuarium i poniżej dużych aglomeracji miejskich. Wykazano silną korelację między zawartością $\mathrm{Pb}, \mathrm{Cd}, \mathrm{Cu}$ i Zn, co sugeruje wspólne pochodzenie tych metali. Analizowane pierwiastki metaliczne stanowią ślad zanieczyszczeń antropogenicznych. Pomimo ochrony wód przez oczyszczalnie ścieków, zanieczyszczenie rzeki Seybouse pozostaje nadal poważnych problemem, z którym powinny się zmierzyć lokalne władze.

Stowa kluczowe: basen Guelma - Annaba, metale ciężkie, osady, rzeka Seybouse, zanieczyszczenie 